\title{
LINC00598 wt Allele
}

National Cancer Institute

\section{Source}

National Cancer Institute. LINC00598 wt Allele. NCI Thesaurus. Code C155733.

Human LINC00598 wild-type allele is located in the vicinity of $13 q 14.11$ and is approximately $457 \mathrm{~kb}$ in length. This allele, which encodes long intergenic non-protein coding RNA 598, may play a role in tumorigenesis. A translocation t(12;13)(p13;q14) involving this gene and the ETV6 gene is associated with B-cell acute lymphoblastic leukemia. 